ACTA AGROBOTANICA

Vol. 61 (2): 65-73

2008

\title{
CO-OCCURRENCE OF AIRBORNE ALLERGENIC POLLEN GRAINS AND FUNGAL SPORES IN RZESZÓW, POLAND (2000-2002)
}

\author{
Idalia Kasprzyk \\ Department of Environmental Biology, University of Rzeszów, Rejtana 16c, 35-959 Rzeszów, Poland
e-mail: idalia@univ.rzeszow.pl
}

Received: 17.10.2008

\begin{abstract}
$\mathrm{Su} \mathrm{m} \mathrm{m} \mathrm{a} \mathrm{r} \mathrm{y}$
The co-occurrence of airborne allergenic pollen grains and fungal spores was estimated in Rzeszów in the years 20002002. The volumetric method was used in this aerobiological study. Six taxa of pollen grains and five types of fungal spores characterized by strong allergenicity and/or high concentrations in the air were analyzed. The time series of pollen grains and fungal spores were compared using PCA analysis. The periods of the greatest concentrations of tree pollen did not coincide with similar periods for herbaceous plants and fungal spores. From February to mid-March, Alnus pollen dominated in the air. The second period was characterized by Betula pollen. It occurred in April. Herbaceous pollen and fungal spores occurred in the air simultaneously (from mid May to the end of August), creating a risky situation for sensitized people. The periods of the highest concentrations of Epicoccum and Ganoderma fungal spores did not coincide with the same period for the examined plant taxa. In Rzeszów the probability of becoming exposed to very high concentrations of allergenic pollen and fungal spores at the same time was high, especially in July, when the highest concentrations of Poaceae, Alternaria and Cladosporium were noted. The hypersensitivity to only one plant or fungal allergen is rarely encountered. Under the present scenarios of global warming, pollen seasons of many taxa will be longer and sufferers will have year-long symptoms.
\end{abstract}

Key words: aeroallergens, fungal spore, pollen, pollen season, threshold value

\section{INTRODUCTION}

Viruses, bacteria, yeasts, fungal spores, pollen belong to particles naturally occurring in air, but from the point of view of medicine they can be regarded as bioaerosol (Ad a m s, 1964; C o r d e n et al. 2003; We ryszko-Chmielewska and Piotrowska, 2004; Bugajny et al. 2005; Myszkowska, 2006; K a s przy k, 2006; S m ith et al. 2007). These particles occur in the atmosphere during almost all year and affect human health (E m e ry k et al. 2004;
Atkinson et al. 2006). Numerous authors found close associations between the occurrence of airborne pollen grains and fungal spores and the increasing incidence of allergy or even a death (Targ o n s k i et al. 1995; Frei and Leushner, 2000; Kurup et al. 2002; Mys zkow s ka, et al 2002; D' A mato et al. 2007; S mith et al. 2007). The knowledge of the periods of occurrence and of concentrations of all aeroallergens is highly important in determining the etiology of inhalation allergies and their future treatment. In aerobiological papers pollen grains and fungal spores are usually approached separately. In standard aerobiological investigations several allergenic pollen taxa are taken into consideration (A r o b b a et al. 2000; C lot, 2003; We ry s zk o-Ch mi e lew ska and Piotrowska, 2004; Myszkowska, 2006; S t a c h, 2006). With respect to fungal spores, Cladosporium and Alternaria are the most frequently identified in continuous monitoring ( $\mathrm{S}$ tę p a l s k a et al. 1999; C ord e n etal. 2003; H o 11 in s et al. 2004; Grinn-Gofroń, 2007; Grinn-Gofroń and $\mathrm{Mik} \mathrm{a,2008),} \mathrm{however,} \mathrm{the} \mathrm{list} \mathrm{of} \mathrm{fungal} \mathrm{spores} \mathrm{cau-}$ sing inhalation allergies is long. Here belong conidial spores (like Epicoccum), basidiospores (like Ganoderma) and also ascospores (Didymella). Currently, about 70 fungal allergens have been approved ( $\mathrm{K} \mathrm{u} \mathrm{r} \mathrm{u} \mathrm{p} \mathrm{et}$ al. 2002; Bus h and P ortnoy, 2001).

The occurrence of airborne sporomorphs is characterized by seasonal and temporal variability affected by weather and type of climate, thermal turbulence and stability, geobotanical characteristics (Stępalska et al. 1999; A robba et al. 2000; Frei and Leushner, 2000; Corden et al. 2003; Hollins et al. 2004; Stępalska and Wołek, 2005; K a s przy k, 2006; M y s z k ow s k a, 2006; Weryszko-Ch m i e lew ska et al.2006; S m ith et al. 2007; Grinn-Go frońa and Mika, 2008). These factors interact synergistically or infinitively. 
The co-occurrence of many allergenic pollen grains in the air might have a cumulative effect on allergy sufferers $(\mathrm{Hje} \mathrm{lmroos}-\mathrm{Koski}$ et al. 2006; Ranta and Satri, 2007). The aim of the present work was to determine if and to what extent the seasons of maximum concentrations of airborne allergenic airborne pollen and fungal spores overlap.

\section{MATERIALS AND METHODS}

Aerobiological investigations were carried out in Rzeszów in the years 2000-2002 using the volumetric method. Sporomorphs are identified on the basis of their morphology; it is not possible to estimate their viability. The monitoring was continuously conducted using a Hirst type volumetric spore trap (Lanzoni VPPS 2000) situated about $12 \mathrm{~m}$ above the ground level. For each day of the year, a microscopic slide was made and subjected to qualitative and quantitative analysis. Samples were examined at x 400 magnification for pollen grains and at x 600 magnification for fungal spores using light microscopy. Pollen grains were counted along 12 latitudinal transects on each microscope slide, fungal spores samples from one horizontal sweep. The results were expressed as daily average pollen grains/ fungal spores in cubic metre.

Six taxa of pollen grains and five types of fungal spores characterized by strong allergenicity and/or high concentrations in the air were analyzed. The start and the end of pollen/fungal seasons were determined when the cumulative sum of sporomorphs reached $5 \%$ and $95 \%$ of the total sum, respectively. The number of days above the threshold value in the season was selected on the basis of literature data (R a p i e j ko, 1995; J äg e r, 1998; R a p i j k o et al. 2004).

The times series of pollen grains and fungal spores were compared using PCA analysis (Principal Component Analysis). Each of three components carried independent information. In the results, several groups of the examined factors were created, ranked according to their numerical importance. Taxa (factors) can be grouped in many respects: frequency, time of pollen seasons. The first component gives the highest percentage of explained variance, but the others can highlight additional, important information. The number of factors was chosen according to Kaiser's criterion. The obtained results were compared with these from the CONSLINK method (dendrogram). Numerical analyses were done with Polpal ( $\mathrm{N}$ a 1 e p $\mathrm{ka}$ and Wal an us, 2003). Days of year (365) were grouped into pentads (73).

\section{RESULTS}

Of the investigated taxa, alder (Alnus) pollen showed the greatest variability in the dates and length of atmospheric seasons and the number of days above the threshold value. In 2002 the pollen season started at the beginning of February but in 2001 about one month later (Tab. 1). The length of pollen seasons ranked between 15 and 62 days. The number of days above the threshold value ranged between 6 and 13 and was not connected with the pollen season length. In 2000 and 2001 the airborne Betula pollen seasons occurred by the end of April, but in 2002 in April. The period of the highest pollen concentrations was very short. The numbers of days dangerous for sensitive people were almost the same in all the years, e.g. 12-13 days. In the second half of May, the start of the Poaceae pollen seasons was noted, then, of the Urtica pollen seasons in the middle of June. In all the years, the pollen seasons of Poaceae and Urtica were very long, e.g. above two months. Among the plant taxa, the number of days above the threshold value for Poaceae and Urtica was the highest - about fifty. The maximum concentrations of mugwort (Artemisia) pollen grains occurred in August. Single grains were noted in September and even to October. For about 10 days, sensitive people were exposed to a dangerous Artemisia pollen concentration. The atmospheric Ambrosia pollen seasons were characterized by high variability. Ragweed pollen release started in August and maximum pollen concentrations were usually noted at the end of August and at the beginning of September. In 2000 single pollen grains of Artemisia and Ambrosia remained in air even until October (Tab. 1, Fig. 1).

Generally, Alternaria fugal spores occurred in air from mid-May to mid-October. For above 30 days people were exposed to dangerous concentrations of fungal spores. The period of the occurrence of Cladosporium spores in air began already at the end of May and usually lasted to mid-October. Mean daily concentrations were the highest among the investigated taxa and the number of days dangerous for allergic people was very high, too. The remaining fungal spores appeared in air from July to October. The periods of maximum counts of all fungal spores were very long in comparison with the plant pollen seasons (Tab. 1, Fig. 1).

Based on the prepared dendrogram, several periods can be distinguished. From the February to the middle of March, Alnus pollen dominated in the air. The second period was characterized by Betula pollen. It occurred in April. In Rzeszów the pollen seasons of Alnus and Betula did not overlap with the same periods of other strongly allergenic pollen grains and fungal spores.

Herbaceous pollen and fungal spores occurred in the air simultaneously (from mid-May to the end of August). Airborne Urtica, Poaceae pollen grains and Cladosporium spores dominated in this period. 

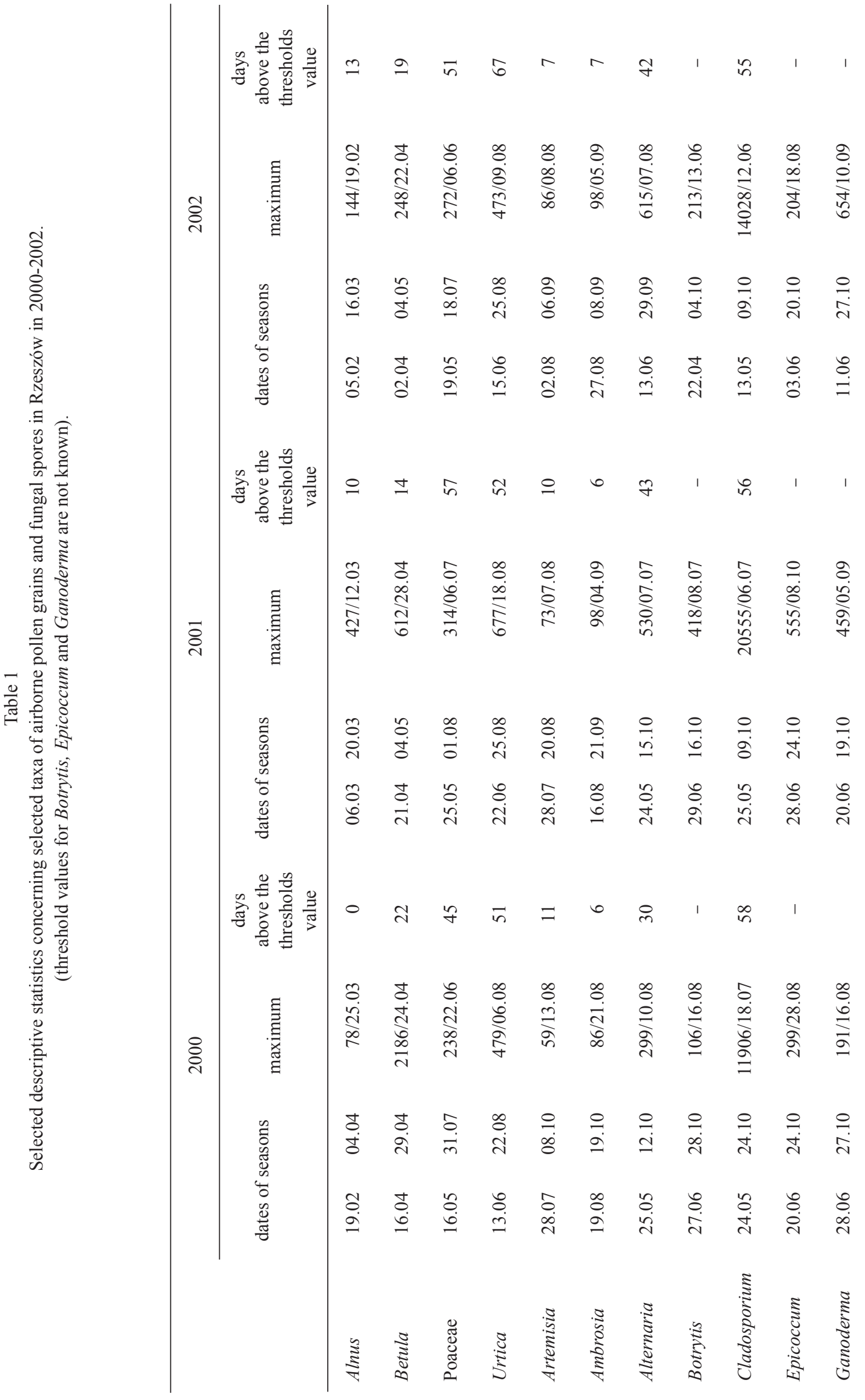
Table 2

Results of PCA analysis for summed three-year percentages of variance explained by three components.

\begin{tabular}{lccc}
\hline & \multicolumn{3}{c}{ Loadings: } \\
\cline { 2 - 4 } Taxa & PCA1 $64 \%$ & PCA2 $12 \%$ & PCA3 $8 \%$ \\
\hline Alnus & 0.79 & -0.38 & -0.16 \\
Potula & 0.13 & 0.84 & -0.36 \\
Urtica & -0.17 & -0.04 & -0.15 \\
Artemisia & -0.24 & -0.16 & -0.11 \\
Ambrosia & -0.06 & -0.04 & -0.00 \\
Alternaria & -0.05 & -0.03 & 0.01 \\
Botrytis & -0.09 & -0.03 & 0.07 \\
Cladosporium & -0.06 & -0.04 & -0.03 \\
Epiccocum & -0.47 & -0.29 & -0.41 \\
Ganoderma & -0.09 & 0.13 & 0.80 \\
& -0.15 & -0.07 & 0.10
\end{tabular}

The number of days when pollen grains and fungal spore concentrations exceeded threshold values at the same time (Poaceae, Artemisia, Alternaria and Cladosporium).

\begin{tabular}{lccc}
\hline Taxa & 2000 & 2001 & 2002 \\
\hline Poaceae/Alternaria & 13 & 12 & - \\
Poaceae/Cladosporium & 31 & 35 & 18 \\
Poaceae/Alternaria/Cladosporium & 13 & 12 & - \\
Artemisia/Alternaria & - & 14 & 13 \\
Artemisia/Cladosporium & - & 9 & 11 \\
Artemisia/Alternaria/Cladosporium & - & 7 & 10 \\
Alternaria/Cladosporium & 24 & 25 & 28
\end{tabular}

In September high concentrations of all the examined fungal taxa were noted. The next period was characterized by high concentrations of airborne Epicoccum, Ganoderma and Cladosporium fungal spores, which occurred in October and November. From December to January, Cladosporium spores predominated in the air (Fig. 1). These results were confirmed by PCA analysis (Tab. 2). On the basis of Kaiser's criterion, three factors were chosen. They explained $64 \%, 12 \%, 8 \%$ of the total variance, respectively. The taxa could be grouped into four groups on the basis of high similarity of the pollen season dates. Alnus and Betula formed two independent groups (the second factor), all herbaceuous pollen taxa, Alternaria, Botrytis and Cladosporium belonged to the third one (the first factor), Epicoccum and Ganoderma were characterized by high similarity (the third factor; Tab. 2). From June to August, the concentrations of pollen grains and fungal spores of several investigated taxa exceeded the threshold values. Pollen concentrations which simultaneously exceeded the threshold values were most frequently observed between Poaceae and Cladosporium (18-35 days), Alternaria and Cladosporium (24-28 days) (Tab. 3 ). 

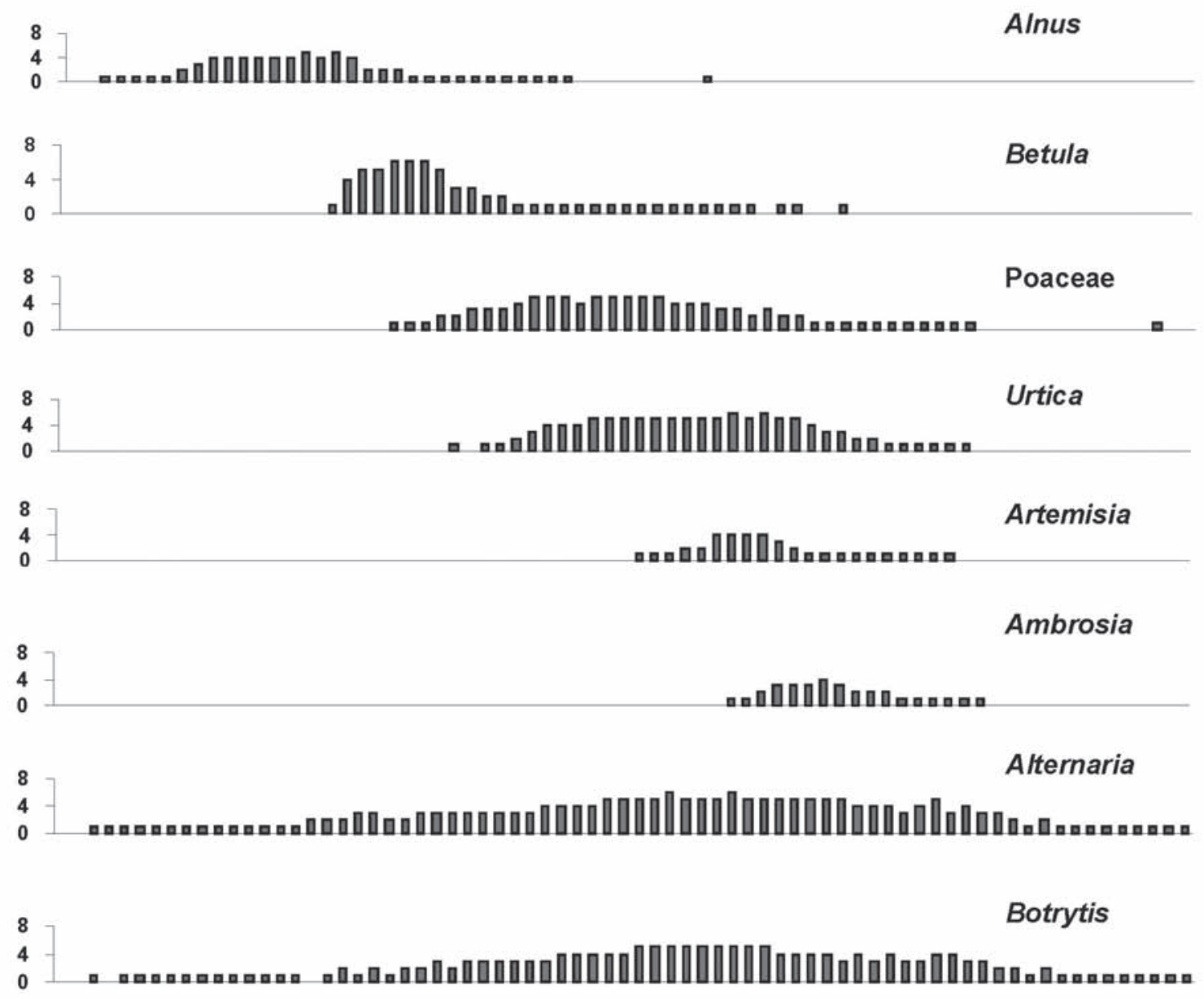

Cladosporium
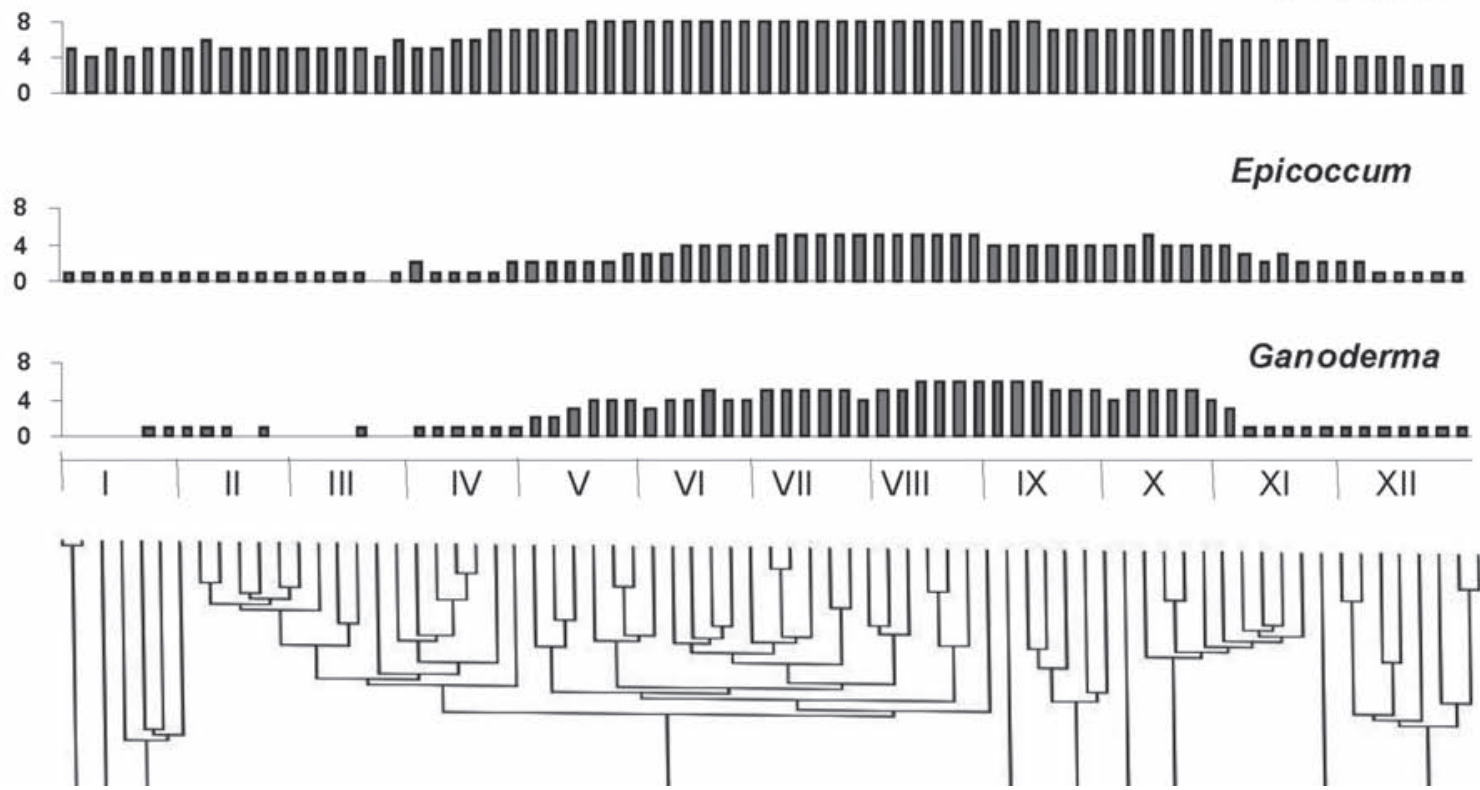

Figure 1. Pollen and fungal spore calendar for Rzeszów (2000-2002);

Ranges 1-8 correspond to average pollen grains/fungal spores concentrations $\left(\mathrm{s} \times \mathrm{m}^{3}\right): 1-10 ; 11-30 ; 31-90 ; 91-270 ; 271-810$; 811-2430; 2431-7290; >7291; dendrogram of pentads (CONSLINK method) based on the occurrence of 11 taxa. 


\section{DISCUSSION}

Pollen grains and fungal spores induce allergy if they occur at a sufficiently high concentration, i.e. a concentration exceeding a threshold value. In the respective literature concerning pollen, varied data are given depending on the geographical region and the phase of the pollen season; some authors claim that this value is associated with individual traits of the patient (Ta rg o n s k i et al. 1995; W a i s e 1, 2003; R a pi j k o et al. 2004; Myszkowska et al. 2002; D' A mato et al. 2007; S mith et al. 2007). Major pollen allergens are structurally and immunochemically similar. We can observe cross-reactions between tree, herbal allergens within one genus, family ( $\mathrm{G}$ a d e rmaier et al. 2004; Mothes and Valenta, 2004; D'A m a to et al. 2007). A paper by P u c (2003) contains a review of the literature.

In the years of the investigation, the phenology of the occurrence of pollen from selected taxa was consistent with the tendencies presented by authors for different regions of Poland (We r y s z ko-Chmielewska and Piotrowska, 2004; Myszkowska, 2006; Stach, 2006). Pollen of trees appeared first, followed by pollen of grasses and, subsequently, of other herbaceous plants. In the second half of the year, the highest concentrations of fungal spores were noted. Aeroallergens usually occur in air throughout a greater part of the vegetation season, which poses a serious problem to allergic people. This phenological cycle is reflected in the specific rhythm of incidence of diseases, i.e. in spring pollen of trees causes the so-called spring pollinosis, of grasses and cereals - the summer incidence, and pollen of other herbaceous plants, the late-summer form of this disease (Frei and Leushner, 2000).

Hjelmroos-Koski et al. (2006) suggest that, instead of that, individual taxa pollen and fungal spores should be grouped and then used to describe daily exposures for sufferers. Allergic pollen grains and fungal spores occurred in air during almost the whole year, from early spring to late autumn. Alnus sp. starts pollen shedding in very instable weather conditions before leaf development (Weryszko-Chmielewska and Piotrowska 2004; Kasprzyk, 2006; Emberlin et al. 2007b; $\mathrm{S} \mathrm{mith} \mathrm{et} \mathrm{al.} \mathrm{2007).} \mathrm{In} \mathrm{favorable} \mathrm{temperature,} \mathrm{first}$ airborne pollen grains can occur in January, when temperature is low for a long time, and the start of the pollen season is noted at the end of March. Betula sp. requires higher temperature to start flowering and leafing (Weryszko-Chmielewska et al. 2006; Emberlin et al. 2007a; Ranta and Satri, 2007). The pollen seasons of these taxa did not overlap and they created two independent time series, but in 2000 the Betula pollen season started only 12 days after the end of the Alnus pollen season. Because of cross-reactivity, Alnus pollen has a priming effect on allergic people before the start of the Betula season. Under the present scenarios of global warming, the tree pollen seasons will start earlier and be longer, and sufferers will be exposed to allergenic tree pollen throughout all spring (E m b e r lin et al. 2007a; R a n ta and S a tri, 2007). Frei and Le uschner (2000) report that in Switzerland the sensitivity to tree pollen is observed to increase together with the tendency to its increased concentrations in air. As far as the Polish population is concerned, the first symptoms from the nose in $25 \%$ of examined people were noted when Betula and Alnus pollen concentrations were relatively low, at 20 and 45 grains $/ \mathrm{m}^{3}$, respectively (R a p i e j k o et al. 2004). A constant increase in total airborne pollen counts of early-flowering trees has been found in many European cities ( C l o t , 2003; Phenology and human health... 2003). In Poznań, Poland, and Worcester, UK, a trend toward longer Alnus pollen season was found ( $\mathrm{S} \mathrm{m} \mathrm{i} \mathrm{th}$ et al. 2007), and in the future periods with Betula and Alnus pollen concentrations above threshold values might overlap. It can have a strong effect on sufferers.

Herbaceous pollen grains contain similar allergic proteins, which are responsible for extensive crossreactivity among pollen-sensitized patients ( $\mathrm{G}$ a d e $\mathrm{r}$ $\mathrm{m}$ a i e $\mathrm{r}$ et al. 2004). Grass pollen grains are the main cause of allergy in Europe and in Poland, too. According to Rapiejko et al. (2004), in Poland the first symptoms of allergy are noted when a grass pollen concentration exceeds $20 \mathrm{gxm}^{-3}$. Urtica pollen is considered to be weakly allergenic. In the air of Rzeszów, they occurred at very high concentrations together with Poaceae pollen; above the threshold values $\left(50 \mathrm{gxm}^{-3}\right.$; R a p i e j k o, 1995) for 28-13 days. Could it increase allergy symptoms? This problem should be considered with respect to the regions where Urtica pollen concentrations are very high, i.e. in Lublin (Wery s zko-Chmielewska and Pi otrowska, 2004).

Ambrosia pollen is considered to be highly allergenic even in low concentrations. In Rzeszów and other Polish cities, the number of days exceeding the threshold value $\left(20 \mathrm{gxm}^{-3}\right.$; J ä ge r, 1998) is low (Weryszko-Chmielewska and Piotrowska, 2004; Myszkowska, 2006; S ta ch, 2006), but episodes of high or very high concentrations were noted in several cities in Poland ( $\mathrm{S} \mathrm{m}$ it h et al. 2008). It should be stressed that many Polish patients had a positive skin prick test to ragweed pollen (Stę pals ka et al. 2002). Global warming may augment Ambrosia pollen production and intensify cross-reactive allergies with other pollens (W a n et al. 2002).

The results concerning the seasonal occurrence of airborne fungal spores do not differ from Polish literature data (S tę palska et al. 1999; Bugajny et 
al. 2005; S tę p a ls k a and Wołe k, 2005; GrinnGo froń, 2007; 2008). Fungi are cosmopolitan organisms; they occur in outdoor and indoor environs (B u g a j n y et al. 2005) and are known as common pathogens. Botrytis sp. attacks strawberry, tomato, cucumber, cabbage, which fruit in summer. Alternaria sp. is known as a common pathogen of cereals, and spore concentrations increase above the threshold value during harvest time (in August) when high concentrations of grass pollen are usually noted. Other fungi are common on dead parts of numerous plants, seeds, soft fruits, and their airborne spores can occur abundantly in the second part of the growing season. The role of fungal spores in causing allergy symptoms is not sufficiently known yet. The list of allergenic spores is long; however, the threshold values are not sufficiently recognized. Alternaria alternata is one of the most important among all allergenic fungi and its threshold value for the first symptoms is 80 spores $\times \mathrm{m}^{3}$ ( $\mathrm{R}$ a p i e j k o et al. 2004). Airborne spores of Cladosporium herbarum are widely found throughout all the world. About 60 allergens from this species have been identified, and a dangerous concentration value is between 2800 and 5000 spores $\times \mathrm{m}^{3}$ (R a p i e j k o et al. 2004). Ta r g o n s k y et al. (1995) reported the odds of a death by asthma occurring on days when critical values were above 2000 spores $/ \mathrm{m}^{3}$.

In Rzeszów, the probability of becoming exposed to very high concentrations of allergenic pollen and fungal spores at the same time was high, especially in July, when the highest concentrations of Poaceae, Alternaria and Cladosporium were noted. Potentially, people suffering from asthma caused by fungal spores can manifest allergy to herbaceous pollen. This problem should be considered because a trend noted toward a higher total annual sum of not only pollen grains, but also fungal spores (C o r d e n et al. 2003).

Climate change has an impact on the start and length of the pollen season, pollen production and phenological phenomena. In Europe the length of the growing season has increased by 10-11 days over 30 years. Also, changes in the pollen season have been observed. An earlier start, peak and end of the pollen season have been evident in species that flower in early spring (Corylus, Alnus, Betula, Populus; Clot, 2003; E m b e r lin et al. 2007a). The pollen season has become longer, in particular for species flowering in summer. Over 28 years, in Europe the end of the Poaceae, Artemisia, Urtica, Ambrosia pollen seasons has tended to occur later (Wan et al. 2002; P h e nology and hum an health ... 2003). It will be possible that the pollen seasons of many taxa will overlap. In some areas, non-monosensitized patients will have year-long symptoms (D'A m a t o et al. 2007).

The research was done thanks to the KBN grant no. 6 PO468720.

\section{REFERENCES}

Adams K. F. 1964. Year to year variation in the fungus spore content of the atmosphere. Acta Allergol. 19: 11-50.

Arobba D., Guido M. A., Minale P., Montanari C., Placereani S., Pracilio S., Troise C., Voltolini S., Negrini A. C. 2000. Airborne pollen in Genoa (NWItaly): a comparison between two pollen-sampling stations. Aerobiologia, 16: 233-243.

Atkinson R. W., Strachan D. P., Anderson H. R., Hajat S., Emberlin J. 2006. Temporal associations between daily counts of fungal spores and asthma exacerbations. Occup. Environ. Med. 63: 0-590.

Bugajny A., Konopkiewicz M., Piotraszewska-Pająk A., Sekulska-Stryjakowska M., Stach A., Filipiak M. 2005. On the microbiological quality of the outdoor air in Poznań, Poland. Polish J. Environ. Studies, 14: 287-293.

Bush R. K., Portnoy J. M. 2001. The role and abatement of fungal allergens in allergic diseases. J. Allergy. Clin. Immunol. 107: 30-440.

Clot B. 2003. Trends in airborne pollen: an overview of 21 years of data in Neuchâtel (Switzerland). Aerobiologia, 19: 227-234.

Corden J., Millington W. M., Mullins J. 2003. Longterm trends and regional variation in the aeroallergen Alternaria in Cardiff and Derby UK - are differences in climate and cereal production having an effect? Aerobiologia, 19: 191-199.

D’ Amato G., Cecchi L., Bonini S., Nunes C., Annesi-Maesano I., Behrendt H., Liccardi G., Popov T., Van Cauwenberge P. 2007. Allergenic pollen and pollen allergy in Europe. Allergy, 62: 976-990.

Emberlin J., Laaidi M., Detandt M., Gehrig R., Jäger S., Myszkowska D., Nolard N., Rantio-Lehtimak i A., Stach A. 2007a. Climate change and evolution of the pollen content of the air in seven European countries: the example of birch. Revue Francaise d' Allergologie et d'Immunologie Clinique, 47 (2): 57-63.

Emberlin J., Smith M., Close R., Adams-Groom B. 2007b. Changes in the pollen seasons of the early flowering trees Alnus spp. and Corylus spp. in Worcester United Kingdom 1996-2005. Int. J. Biometeorol. 51 (3): 181-191.

Emeryk A., Chojna E., Bartkowiak-Emeryk E., Postępski J. 2004. Prevalence of asthma and some respiratory symptoms in the years 1995 and 2001 in schoolchildren from rural regions of Poland. Ann. Agric. Environ. Med. 11: 63-66.

Frei T., Leushner R. M. 2000. A change from grass pollen induced allergy to tree pollen induced allergy: 30 years of pollen observation in Switzerland. Aerobiologia, 16: 407-416.

Gadermaier G., Dedic A., Obermeyer G., Frank S., Himly M., Ferreira F. 2004. Biology of weed pollen allergens. Curr. Allergy Asthma Rep. 4: 391-400. 
Grinn-Gofron A. 2007. The Cladosporium spores in the air of Szczecin. Acta Agrobot. 60 (2): 99-104.

Grinn-Gofroń A., Mika A. 2008. Selected airborne allergenic fungal spores and meteorological factors in Szczecin, Poland, 2004-2006. Aerobiologia, 24 (2): 89-97.

Hjelmroos-Koski M. K., Macher J. M., Hammond K., Tager I. 2006. Considerations in the grouping of plant and fungal taxa for an epidemiologic study. Grana, 45: 261-287.

Hollins P. D., Kettlewell P. S., Atkinson M. D., Stephenson D. S., Corden J., Millington W. M., Mullins J. 2004. Relationships between airborne fungal spore concentration of Cladosporium and the summer climate at two sites in Britain. Int. J. Biometeorol. 48: 137-141.

Jäger S. 1998. Global aspect of ragweed in Europe. [In:] Spieksma F. Th.M. (ed.) Satellite Symposium Proceedings: Ragweed in Europe. 6th International Congress on Aerobiology. ALK Abelló, Perugia (Italy): 6-10.

Kasprzyk I. 2006. Pyłek wybranych taksonów roślin w powietrzu Rzeszowa, 2001-2005. / Pollen of selected plant taxa in the air of Rzeszów, 2001-2005. [In:] Weryszko-Chmielewska E. (ed.) Pyłek roślin w aeroplanktonie różnych regionów Polski. / Plant pollen in aeroplankton of different regions of Poland. Wyd. Katedry i Zakładu Farmakognozji Wydziału Farmaceutycznego AM w Lublinie, Lublin, 93-103.

Kurup V. P., Shen H. D., Vijay H. 2002. Immunobiology of fungal allergens. Int. Arch. Allergy Immunol. 129: 181-188.

Mothes N., Valenta R. 2004. Biology of tree pollen allergens. Curr. Allergy Asthma Rep. 4: 384-390

Myszkowska D. 2006. Pyłek wybranych taksonów roślin w powietrzu Krakowa, 2001-2005. / Pollen of selected plant taxa in the air of Kraków, 2001-2005. [In:] Weryszko-Chmielewska E. (ed.) Pyłek roślin w aeroplanktonie różnych regionów Polski. / Plant pollen in aeroplankton of different regions of Poland. Wyd. Katedry i Zakładu Farmakognozji Wydziału Farmaceutycznego AM w Lublinie, Lublin, 21-30.

Myszkowska D., Stępalska D., Obtułowicz K., Porębski G. 2002. The relationship between airborne pollen and fungal spore concentrations and seasonal pollen allergy symptoms in Cracow in 1997-1999. Aerobiologia, 18: 153-161.

Nalepka D., Walanus A. 2003. Data processing in pollen analysis. Acta Paleobot. 43 (1): 125-134.

Phenology and human health: Allergic disorders. 2003: Report on a WHO meeting. Rome, Italy 16-17 January.

Puc M. 2003. Characterization of pollen allergens. Ann. Agric. Environ. Med. 10: 143-149.

Ranta H., Satri P. 2007. Synchronized inter-annual fluctuation of flowering intensity affects the exposure to allergenic tree pollen in North Europe. Grana, 46: 274-284.

Rapiejko P. 1995. Pollen monitoring in Poland.[In:] Śpiewak R. (ed.) Pollen and Pollinosis: Current Problems. Institute of Agricultural Medicine.:18-20,
Rapiejko P., Lipiec A., Wojdas A., Jurkiewicz D. 2004. Threshold pollen concentration necessary to evoke allergic symptoms. Int. Rev. Allergol. Clin. Immunol. 10 (3): 91-94.

Smith M., Emberlin J., Stach A., Czarnecka-Operacz M., Jenerowicz D., Silny W. 2007. Regional importance of Alnus pollen as an aeroallergen: A comparative study of Alnus pollen counts from Worcester (UK) and Poznań (Poland). Ann. Agric. Environ. Med. 14: 123-128.

Smith M., Skjǿth C. A., Myszkowska D., Uruska A., Puc M., Stach A., Balwierz Z., Chłopek K., Piotrowska K., Kasprzyk I., Brandt J. 2008. Longrange transport of Ambrosia pollen to Poland. Agric. For. Meteorol. 148: 1402-1411.

Stach A. 2006. Pyłek wybranych taksonów roslin w powietrzu Poznania, 2001-2005. / Pollen of selected plant taxa in the air of Poznań, 2001-2005. [In:] Weryszko-Chmielewska E. (ed.) Pyłek roślin w aeroplanktonie różnych regionów Polski. / Plant pollen in aeroplankton of different regions of Poland. Wyd. Katedry i Zakładu Farmakognozji Wydziału Farmaceutycznego AM w Lublinie, Lublin: 31-47.

Stępalska D., Harmata K., Kasprzyk I., Myszkowska D., Stach A. 1999. Occurrence of airborne Cladosporium and Alternaria spores in southern and central Poland in 1995-1996. Aerobiologia, 15: 39-47.

Stępalska D., Szczepanek K., Myszkowska D. 2002. Variation in Ambrosia pollen concentration in southern and central Poland in 1982-1999. Aerobiologia, 18: 1322.

Stępalska D., Wołek J. 2005. Variation in fungal spore concentrations of selected taxa associated to weather conditions in Cracow, Poland, in 1997. Aerobiologia, 21: 43-52.

Targonski P. V., Persky V. W., Ramakri'shnan V. 1995. Effect of environmental molds on risk of death from asthma during the pollen season. J. Allergy Clin. Immunol. 95: 995-961.

Waisel Y. 2003. Determination of threshold levels: confronting the impossible? Prologue to the "threshold session discussion. [In]: Third European Symposium On Aerobiology. Worcester, UK: 60-61.

Wan S., Yuan T., Bowdish S., Wallace L., Russel S. D., Luo Y. 2002. Response of an allergenic species, Ambrosia psilostachya (Asteraceae), to experimental warming and clipping: implications for public health. Am. J. Bot. 89: 1843-1846.

Weryszko-Chmielewska E., Piotrowska K. 2004. Airborne pollen calendar of Lublin, Poland. Ann. Agric. Environ. Med. 11: 91-97.

Weryszko-Chmielewska E., Puc M., Piotrowska K. 2006. Effect of meteorological factors on Betula, Fraxinus and Quercus pollen concentrations in the atmosphere of Lublin and Szczecin, Poland. Ann. Agric. Environ. Med. 13: 243-249. 


\section{Współwystępowanie alergennych ziaren pyłku i zarodników grzybów w powietrzu Rzeszowa, Polska (2000-2002).}

Streszczenie

Współwystępowanie alergizującego pyłku roślin oraz zarodników grzybów w powietrzu Rzeszowa badano przez okres 3 lat (2000-2002). Pomiary przeprowadzono metodą wolumetryczną. Do analizy wybrano sześć taksonów ziaren pyłku i pięć typów zarodników grzybów charakteryzujących się silną alergennością i/lub wysokimi stężeniami w powietrzu. Taksony, których okresy maksymalnych stężeń pokrywały się, zostały grupowane na podstawie analizy PCA.
Na podstawie dendrogramu (metoda ConsLink) wyznaczono okresy charakteryzujące się podobieństwem przebiegu sezonów pyłkowych analizowanych taksonów. Od lutego do marca w powietrzu dominował pyłek olszy (Alnus), w kwietniu brzozy (Betula). Okres maksymalnych koncentracji pyłku drzew w powietrzu nie pokrywał się z podobnym okresem roślin zielnych i zarodników grzybów. Sezony pyłkowe roślin zielnych i okresy występowania maksymalnych stężeń zarodników grzybów pokrywały się w czasie (od maja do sierpnia). Według obecnych prognoz, na skutek ocieplania się klimatu, sezony pyłkowe będą się wydłużać. Ponieważ rzadko stwierdza się nadwrażliwość tylko na jeden alergen roślinny lub grzybowy okres zagrożenia dla alergików może znacząco się wydłużyć. 